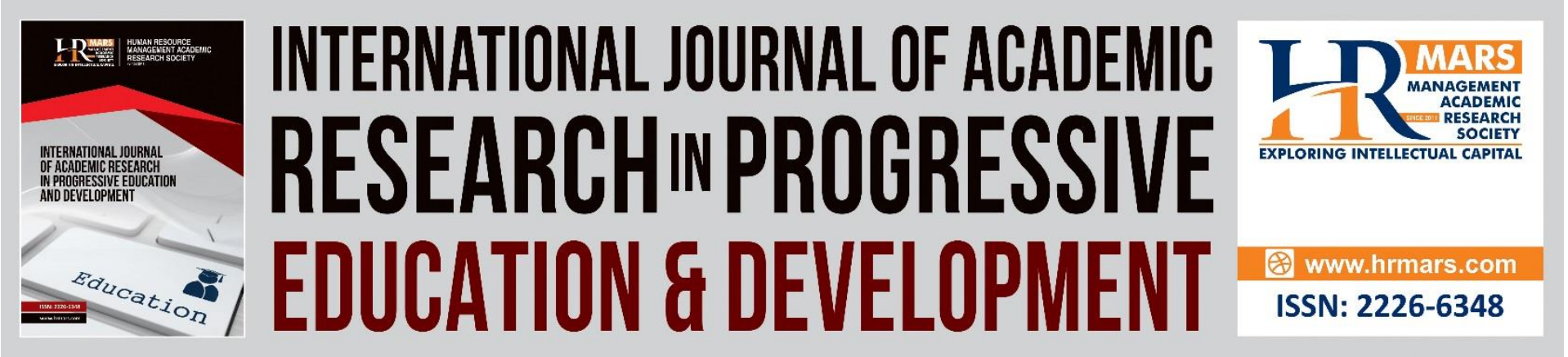

\title{
Strength properties of Lightweight Foamed Concrete with the Presence of Additives
}

\section{Md Azree Othuman Mydin}

To Link this Article: http://dx.doi.org/10.6007/IJARPED/v11-i1/12073

DOI:10.6007/IJARPED/v11-i1/12073

Received: 15 November 2021, Revised: 20 December 2021, Accepted: 10 January 2022

Published Online: 26 January 2022

In-Text Citation: (Mydin, 2022)

To Cite this Article: Mydin, M. A. O. (2022). Strength properties of Lightweight Foamed Concrete with the Presence of Additives. International Journal of Academic Research in Progressive Education and Development, 11(1), 387-394.

Copyright: (c) 2022 The Author(s)

Published by Human Resource Management Academic Research Society (www.hrmars.com)

This article is published under the Creative Commons Attribution (CC BY 4.0) license. Anyone may reproduce, distribute, translate and create derivative works of this article (for both commercial and non-commercial purposes), subject to full attribution to the original publication and authors. The full terms of this license may be seen

at: http://creativecommons.org/licences/by/4.0/legalcode

Vol. 11(1) 2022, Pg. 387 - 394

Full Terms \& Conditions of access and use can be found at http://hrmars.com/index.php/pages/detail/publication-ethics 


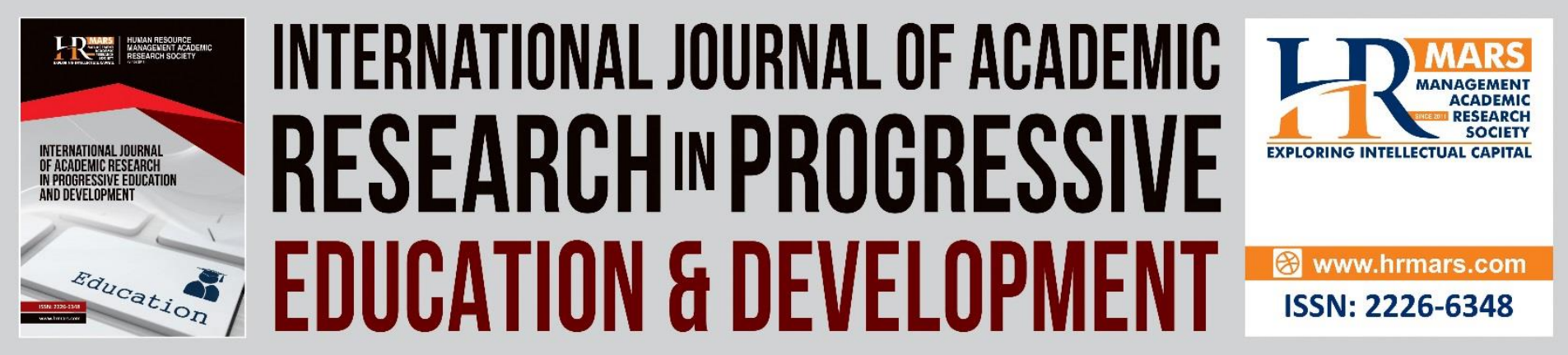

\title{
Strength Properties of Lightweight Foamed Concrete with the Presence of Additives
}

\author{
Md Azree Othuman Mydin \\ School of Housing, Building and Planning, Universiti Sains Malaysia, 11800, Penang, \\ MALAYSIA \\ Email: azree@usm.my
}

\begin{abstract}
Foamed concrete was established for void filling and insulation purposes, but the interest is progressively changing towards structural characteristics in today's society. This paper describes the results of experimental study that have been performed to investigate the effects of different densities and additives on the mechanical properties foamed concrete. Additionally, control foamed concrete samples with different densities $\left(500 \mathrm{~kg} / \mathrm{m}^{3}, 1000 \mathrm{~kg} / \mathrm{m}^{3}\right.$ and $1500 \mathrm{~kg} / \mathrm{m}^{3}$ ) and different additives were prepared independently to study the impacts of densities and additives on the mechanical properties correspondingly. The foamed concrete specimens were prepared with locally available materials which are fuel ash, polypropylene fiber, silica fume and coconut fiber. This study has revealed that the compressive strength of foamed concrete was affected by its density due to the percentage of porosity. On the other hand, it was found that foamed concrete sample with coconut fiber yield better enhancement of the mechanical properties. Coconut fiber as reinforcement in foamed concrete is adequate and has high failure strain which can be able to provide a better compatibility between fibers and matrix. Output from this research would give better understanding of the potential utilization of waste by-products and natural fibres in foamed concrete. Foamed concrete can be used as a new energy-conservation and environmental-protection building material, particularly suitable for the construction of monolithic building envelope in Malaysia.
\end{abstract}

Keywords: Lightweight Foamed Concrete, Supplementary Cementing Materials, Natural Fibre, Strength, Coconut Fiber, Silica Fume

\section{Introduction}

Need and use of foamed concrete as building material become privileged in construction industry due to its promising properties such as lighter in weight, superior thermal insulation and durable performance. Foamed concrete is lighter than normal weight concrete due to artificial air bubbles trapped in its cement mortar by means of suitable foaming agent (Jalal et al., 2019). No utilization of coarse aggregate in fabrication of foamed concrete and fine aggregate (sand) can be partially of fully replaced by renewable materials such as pulverized fuel ash, silica fume and coconut fibers. Moreover, foamed concrete has strong potential to be used as structural material. Generally, the strength value for foamed 
concrete of ranging densities between $500 \mathrm{~kg} / \mathrm{m}^{3}$ to $1400 \mathrm{~kg} / \mathrm{m}^{3}$ is from $1 \mathrm{~N} / \mathrm{mm}^{2}$ to $9 \mathrm{~N} / \mathrm{mm}^{2}$ respectively (Raj et al., 2019).

It should be pointed out that the density and porosity play significant role in controlling the strength of foamed concrete (Elrahman et al., 2019). Since early civilization, pozzolan materials has been practice replacing cement or sand in concrete either naturally or artificially. Besides economic and environmental concerns, it has been proven to give enhancements to the strength of foamed concrete as its natural strength is low. Mechanical properties have been one of the fundamental topics to be investigated but there is lack of knowledge in the effects of various types of additives on mechanical properties of foamed concrete.

Even though lightweight foamed concrete has been expansively studied, some limitations such as low flexural strength still restrict its wider applications (Ramli et al., 2013). The strength of foamed concrete is determined by different cementitious materials, cement dosage, mix proportion, water-cement ratio, foam volume, foaming agent, curing method, additive and addition of waste by-product. To a certain extent, the density controls the strength of foamed concrete. Thus, it is always to seek a balance between strength and density, for the purpose to maximize strength while reducing density as much as possible (Munir et al., 2015). Sometimes, this can be achieved through optimizing cementitious materials and selecting high-quality foaming agents and ultralight aggregates. The filler types and inclusion of oil palm biomass will influence the water-solid ratios when concrete density is constant, and the reduction of sand particle size will help to improve strength (Memon et al., 2018).

The pozzolanic effect of fiber biomass waste is to react with the secondary product, $\mathrm{Ca}(\mathrm{OH})_{2}$ (calcium hydroxide, also known as portlandite), of cement hydration to form additional C-S-H gel (secondary $\mathrm{C}-\mathrm{S}-\mathrm{H}$ ). During the pozzolanic reaction, the longer silicate chains are formed as the Ca:Si molar ratio of C-S-H drops (Mydin et al., 2018). This secondary $\mathrm{C}-\mathrm{S}-\mathrm{H}$ reduces the porosity in bulk cement paste and improves the interfacial bond between aggregate particles and fiber, thus increases the strength, density, and ion diffusion resistance of LFC (Fu et al., 2020). Lately, LFC has gained major attention among the industrial players and building material manufacturers owing its excellent thermal and mechanical properties such as high flowability, low self-weight, good thermal performance, and sound insulation properties (Jhatial et al., 2017).

Besides, LFC is an environmentally friendly building material because of its minimal usage of aggregate and high potential to integrate waste material such as natural fibers. Foamed concrete is a mixture of cement paste (slurry) and homogeneous foam introduced using a suitable foaming agent, which can be regarded as self-compacting materials. Foamed concrete has an air content of more than $25 \%$ by volume, thus, distinguishing itself from highly air entrained materials. Even though increasing consideration has been given to foamed concrete worldwide, its application in the context of Malaysian construction industry is still in its infancy (Musa et al., 2018). However, it has been utilized in several housing and void filling project in Malaysia. Hence this research was performed to inspect the potential utilization of additives in foamed concrete to improve its mechanical properties.

\section{Material Constituents}

There were 5 main materials been used to fabricate foamed concrete which were ordinary Portland cement (OPC), fine sand, foaming agent, water and 4 types of additives. The OPC was supplied by YTL Castle Cement Marketing. All the cement used was in good condition and 


\section{INTERNATIONAL JOURNAL OF ACADEMIC RESEARCH IN PROGRESSIVE EDUCATION AND DEVELOPMENT \\ Vol. 11, No. 1, 2022, E-ISSN: 2226-6348 @ 2022 HRMARS}

stored in a covered area. The fine sand utilized in this study was natural fine sand which was obtained from the local supplier. This fine sand had a maximum width of $2 \mathrm{~mm}$ and a 600 micron sieve, and a passage of $60 \%$ to $90 \%$. The suitability of the sand had to follow BS822:1992. To produce stable foam, a protein-based foaming agent was used, precisely Noraite PA-1. The foam was produced by a portable foaming generator machine, namely the Portafoam TM-1 machine. Different types of additives were used in this study such as fuel ash, polypropylene, silica fume and coconut fiber. These additives inclusion was fixed at weight fraction of $0.2 \%$ and $0.4 \%$. For all 9 mixes, the sand-cement ratio was fixed at $1: 1.5$, and the water-cement ratio was 0.4 . Table 1 shows the materials and mix proportions of foamed concrete specimens with different types of additives

Table 1: Materials and mix proportions of foamed concrete specimens with additives

\begin{tabular}{|l|l|c|c|}
\hline Specimens & \multicolumn{1}{|c|}{ Code } & Mix ratio $(c: s: w)$ & Density $\left(\mathrm{kg} / \mathrm{m}^{3}\right)$ \\
\hline Plain foamed concrete & Control & $1: 1.5: 0.45$ & 1000 \\
\hline Fuel Ash (0.2\%) & FA-0.2 & $1: 1.5: 0.45$ & 1000 \\
\hline Fuel Ash (0.4\%) & FA-0.4 & $1: 1.5: 0.45$ & 1000 \\
\hline Polypropylene $(0.2 \%)$ & PF-0.2 & $1: 1.5: 0.45$ & 1000 \\
\hline Polypropylene (0.4\%) & PF-0.4 & $1: 1.5: 0.45$ & 1000 \\
\hline Silica Fume (0.2\%) & SF-0.2 & $1: 1.5: 0.45$ & 1000 \\
\hline Silica Fume (0.4\%) & SF-0.4 & $1: 1.5: 0.45$ & 1000 \\
\hline Coconut Fiber (0.2\%) & CF-0.2 & $1: 1.5: 0.45$ & 1000 \\
\hline Coconut Fiber (0.4\%) & CF-0.4 & $1: 1.5: 0.45$ & 1000 \\
\hline
\end{tabular}

\section{Experimental Setup}

The tests were carried out investigating the mechanical properties with the inclusion of different types of additives which includes flexural test, compression test and splitting tensile test.

\section{Flexural Test}

For the flexural test, prism of $100 \mathrm{~mm} \times 100 \mathrm{~mm} \times 500 \mathrm{~mm}$ was utilized according to ASTM C293 / C293M. Three-point flexural test was opted to obtain the flexural strength of LFC. Three specimens were prepared, and test and average result of flexural test was taken as final result. Figure 1 illustrates the setup for the flexural test.

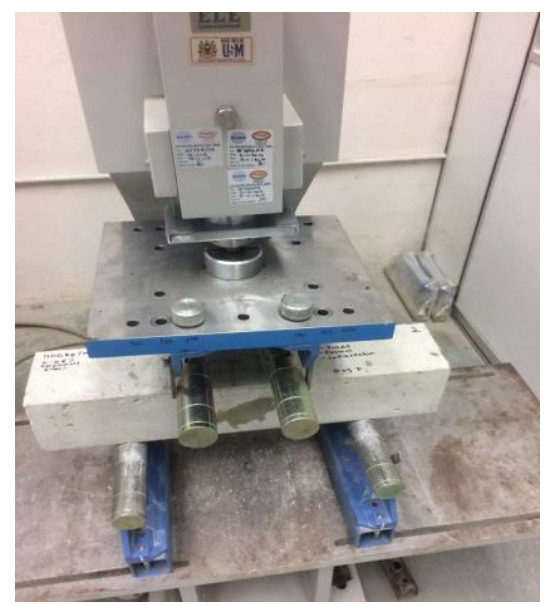

Figure 1. Flexural test of LFC 
INTERNATIONAL JOURNAL OF ACADEMIC RESEARCH IN PROGRESSIVE EDUCATION AND

DEVELOPMENT

Vol. 11, No. 1, 2022, E-ISSN: 2226-6348 @ 2022 HRMARS

\section{Compression Test}

The specimen size for compression test is $100 \mathrm{~mm} \times 100 \mathrm{~mm} \times 100 \mathrm{~mm}$ cube which was performed according to BS EN 12390-3 standard. Figure 2 demonstrates the arrangement of the compression test.

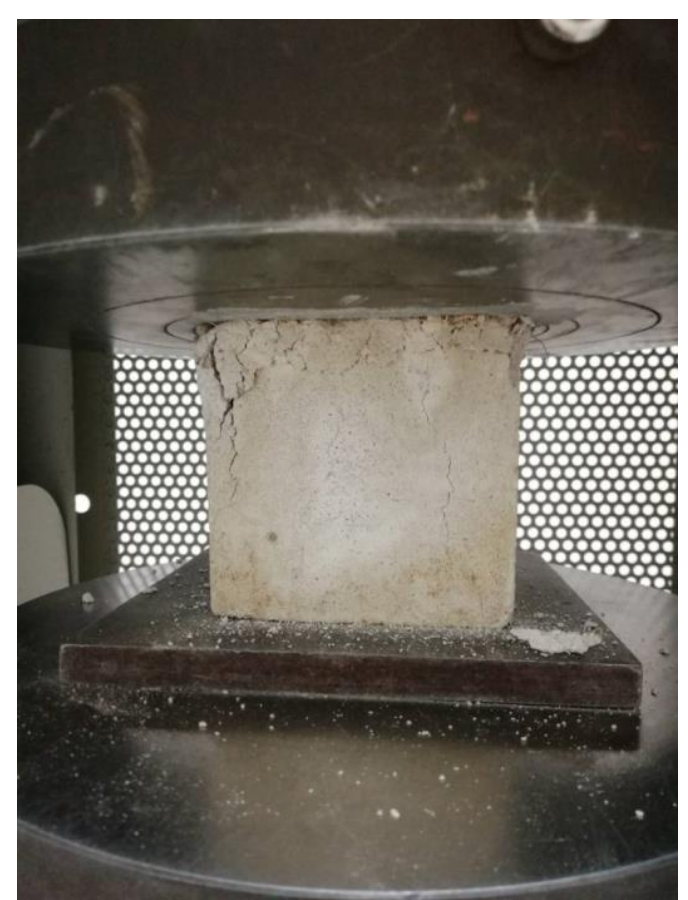

Figure 2. Compression test of LFC

\section{Splitting Tensile Test}

As for splitting tensile strength, cylinder of $100 \mathrm{~mm}$ diameter $\times 200 \mathrm{~mm}$ height was considered according to ASTM C496/C 496M [10] standard. Three specimens were prepared and test and the average reading from these three results of flexural test was taken as the final result. Figure 3 illustrates the setup for the flexural test. The cylindrical specimen was clamped properly to ensure equal distribution of tensile load during the test. 


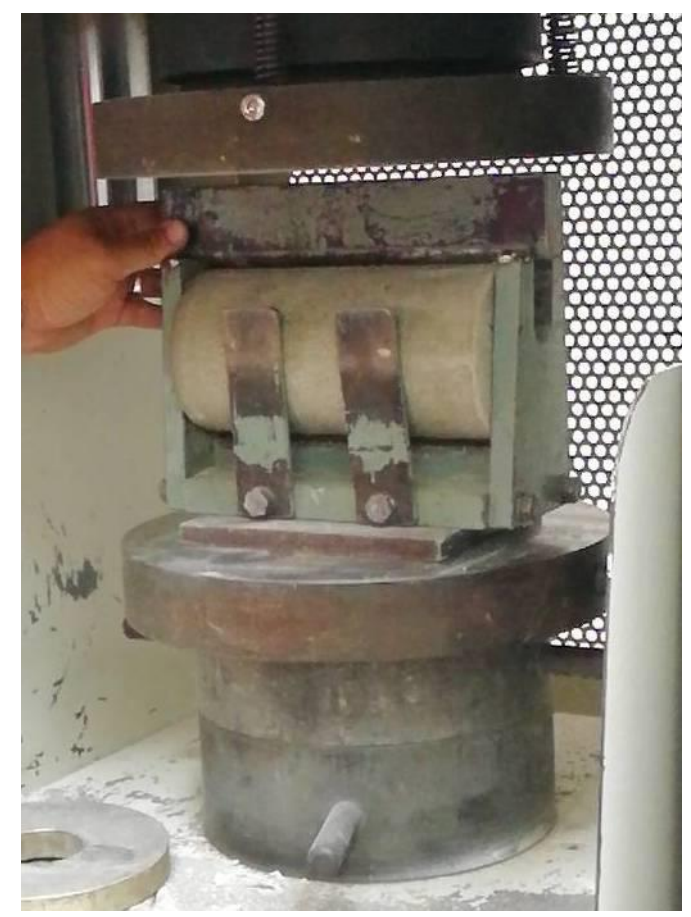

Figure 3. Splitting tensile test arrangement

\section{Results and Discussion}

This section will give comprehensive justifications on the studies of foamed concrete with different densities and additives. Table 2 demonstrates clearly that density influences the mechanical properties due to pores production in foamed concrete. The strength of foamed concrete specimens is parallel with the ages. Low density consumed high dosage of foam; hence its density and value of strength were dropped. High amount of pores induced will create weak cell structure between pores and matrix as there was insufficient surface area that connects pores and matrix. At low density, the pores will fuse close together and some of the bubbles merge with another and creates larger pores, thus cracks easily formed when external forces were applied on the concrete. It should be pointed out that the compressive and flexural strength have similar strength development trend with the splitting tensile strength.

Table 2: Mechanical properties of control foamed concrete specimens of different densities

\begin{tabular}{|l|l|l|l|l|l|}
\hline \multirow{4}{*}{ Tests } & $\begin{array}{l}\text { Density } \\
\left(\mathrm{kg} / \mathrm{m}^{3}\right)\end{array}$ & \multicolumn{4}{l}{ Ages of Testing } \\
\cline { 2 - 7 } & 7 days & 28 days & 56 days & 168 days \\
\hline \multirow{3}{*}{$\begin{array}{l}\text { Compressive Strength } \\
\left(\mathrm{N} / \mathrm{mm}^{2}\right)\end{array}$} & 500 & 0.35 & 0.46 & 0.56 & 0.68 \\
\hline \multirow{3}{*}{$\begin{array}{l}\text { Flexural Strength } \\
\left(\mathrm{N} / \mathrm{mm}^{2}\right)\end{array}$} & 1000 & 1.87 & 2.06 & 2.14 & 2.22 \\
\hline \multirow{3}{*}{$\begin{array}{l}\text { Tensile Strength } \\
\left(\mathrm{N} / \mathrm{mm}^{2}\right)\end{array}$} & 1500 & 5.58 & 7.47 & 9.55 & 10.01 \\
\hline & 500 & 0.24 & 0.31 & 0.37 & 0.39 \\
\hline & 1000 & 0.89 & 0.95 & 1.06 & 1.23 \\
\cline { 2 - 7 } & 1500 & 2.12 & 2.24 & 2.63 & 2.89 \\
\hline
\end{tabular}


DEVELOPMENT

Vol. 11, No. 1, 2022, E-ISSN: 2226-6348 @ 2022 HRMARS

Table 3 illustrates the variations of compressive strength of each additive at different testing ages. Highest strength was produced with large inclusion of coconut fiber as it has larger diameter and high percentage of lignin. As well, it can offer an improved compatibility between fibers and matrix due to its high failure strain. It did not cause the sample break apart, but it will react as a micro crack agent. Next, both percentages of polypropylene fiber have increased the strength of foamed concrete but does not show massive changes from age to age. High inclusion of polypropylene fiber (0.4\%) showed better compressive and flexural strength with some good additional effects because a smaller number of particles are not evenly spread in the whole and later will lead to failure of the particles where it unable to resist the load bearing at the very point of load.

Natural and synthetic additives act as bridging component in foamed concrete during propagation of minor cracks. $0.2 \%$ of silica fume (SF-0.2) shows high early strength compared to other pozzolanic materials. It will improve the strength with the formation of discrete pores due to longer period of hydration process. Besides that, FA- 0.2 and FA-0.4 produced no improvement in the early strength but enormous improvement from 28 days to 168 days. Fuel ash is a weak and unstable pozzolan, so that it was associated with FA to avoid declining in foamed concrete strength. Addition of fuel ash must be lower to reach desired strength due to its high particle size. Ratio of fuel ash will be increased due to the increasing percentage in POFA added and this will reduce the early strength development of foamed concrete.

Table 3: Mechanical properties of foamed concrete with different types of additives.

\begin{tabular}{|c|c|c|c|c|c|c|c|c|c|c|c|c|}
\hline \multirow[t]{3}{*}{ Code } & \multicolumn{4}{|c|}{$\begin{array}{l}\text { Compressive Strength } \\
\left(\mathrm{N} / \mathrm{mm}^{2}\right)\end{array}$} & \multicolumn{4}{|c|}{ Flexural Strength $\left(\mathrm{N} / \mathrm{mm}^{2}\right)$} & \multicolumn{4}{|c|}{ Tensile Strength $\left(\mathrm{N} / \mathrm{mm}^{2}\right)$} \\
\hline & \multicolumn{4}{|c|}{ Ages of Testing (days) } & \multicolumn{4}{|c|}{ Ages of Testing (days) } & \multicolumn{4}{|c|}{ Ages of Testing (days) } \\
\hline & 7 & 28 & 56 & 168 & 7 & 28 & 56 & 168 & 7 & 28 & 56 & 168 \\
\hline Control & 1.87 & 2.06 & 2.14 & 2.22 & 0.89 & 0.95 & 1.06 & 1.23 & 0.20 & 0.23 & 0.26 & 0.27 \\
\hline FA-0.2 & 1.29 & 1.68 & 2.94 & 3.54 & & 0. & & 1.07 & 0.18 & 0.28 & 0.29 & 0.32 \\
\hline FA-0.4 & 1.21 & 1.49 & 1.88 & 2.35 & 0.63 & 0.60 & 0.61 & 0.74 & 0.13 & 0.14 & 0.15 & 0.19 \\
\hline PF-0.2 & 1.78 & 2.08 & 2.47 & 3.15 & 0.85 & 1.11 & 1.19 & 1.25 & 0.22 & 0.30 & 0.32 & 0.34 \\
\hline PF-0.4 & 2.04 & 2.87 & 2.95 & 3.28 & 0.86 & 1.16 & 1.34 & 1.43 & 0.26 & 0.36 & 0.36 & 0.37 \\
\hline SF-0.2 & 1.98 & 2.47 & 2.54 & 2.65 & 0.82 & 0.88 & 0.90 & 0.98 & 0.21 & 0.24 & 0.27 & 0.31 \\
\hline SF-0.4 & 2.16 & 2.75 & 2.79 & 3.01 & 0.99 & 1.01 & 1.07 & 1.21 & 0.25 & 0.28 & 0.30 & 0.32 \\
\hline CF-0.2 & 1.67 & 2.51 & 3.17 & 3.36 & 0.89 & 1.32 & 1.37 & 1.55 & 0.19 & 0.29 & 0.32 & 0.36 \\
\hline CF-0.4 & 1.58 & 2.23 & 4.18 & 4.83 & 0.86 & 1.30 & 1.55 & 1.82 & 0.18 & 0.27 & 0.39 & 0.41 \\
\hline
\end{tabular}

\section{Conclusion}

This study revealed that the mechanical property of foamed concrete is predominantly as a function of density and can be improved with the addition of various types of additives. Formation of larger size of pores and numbers of voids lead to weak bonding between matrix and pores, hence poor mechanical properties at low density. Among the additives, coconut fiber yield better enhancement of the mechanical properties. Short length coir fibres act as reinforcement in foamed concrete and has high failure strain, thus it provides better compatibility between fibers and matrixes. The output of this laboratory investigation would give better insight of the prospective deployment of waste by-products and natural fibres in foamed concrete. Foamed concrete can be employed as a new energy-conservation and 
environmental-protection building material, especially appropriate for the construction of monolithic building envelope in Malaysia.

\section{References}

Elrahman, M. A., El Madawy, M. E., Chung, S. Y., Sikora, P., Stephan, D. (2019). Preparation and characterization of ultra-lightweight foamed concrete incorporating lightweight aggregates. Applied Sciences (Switzerland), 9(7): 1-12

Fu, Y., Wang, X., Wang, L., Li, Y. (2020). Foam Concrete: A State-of-the-Art and State-of-theart Practice Review. Advances in Materials Science and Engineering, 6153602, 1-25

Jalal, M. D., Tanveer, A., Jagdeesh, K., Ahmed, F. (2017). Foam concrete. International Journal of Civil Engineering Research, 8(1): 1-14 Hedjazi S. (2019). Compressive Strength of Lightweight Concrete. In Intech Open:1-18

Memon, I. A., Jhatial, A. A., Sohu, S., Lakhiar, M. T., Hussain Z. (2018). Influence of Fibre Length on the Behaviour of Polypropylene Fibre Reinforced Cement Concrete. Civil Engineering Journal, 4(9): 2124-2131.

Munir, A., Abdullah, Huzaim, Sofyan, Irfandi, \& Safwan. (2015). Utilization of palm oil fuel ash (POFA) in producing lightweight foamed concrete for non-structural building material. Procedia Engineering, 125, 739-746.

Musa, M., Mydin, O. M. A., Abdul Ghani, A. N. (2019). Thermal properties of foamed concrete with addition of empty fruit bunch (EFB) fiber. International Journal of Innovative Technology and Exploring Engineering. 8(10):4662-4670

Mydin, M. A. O., Zamzani, N. M., Ghani, A. N. A. (2018). Effect of alkali-activated sodium hydroxide treatment of coconut fibre on mechanical properties of lightweight foamed concrete, in 3rd International Conference on Applied Science and Technology. 5055512:020108.

Raj, A., Sathyan, D., Mini, K. M. (2019). Physical and functional characteristics of foam concrete: A review. Construction and Building Materials. 221:787-799.

Ramli, M., Kwan, W. H., Abas, N. F. (2013). Strength and durability of coconut-fibre-reinforced concrete in aggressive environments. Construction and Building Materials. 38:554-566. 